DOI: 10.34015/2523-4552.2020.1.09

удк 343.8

Макаренко Н. К., кандидат юридичних наук, доцент, здобувач кафедри кримінології та кримінально-виконавчого права Національної академії внутрішніх справ ORCID: 000-0003-3089-3535

\title{
НЕЙТРАЛІЗАЦІЯ КРИМІНОГЕННОСТІ МІСЦЬ ПОЗБАВЛЕННЯ ВОЛІ ЯК НАПРЯМ ЗАПОБІГАННЯ ПРОФЕСІЙНІЙ ЗЛОЧИННОСТІ
}

У статті досліджується проблема нейтралізації криміногенності місць позбавлення волі та її вплив на професійну злочинність. Звертається увага на необхідність обов'язкового впровадження заходів індивідуального запобігання професійній злочинності. Визначено, що заходи нейтралізації криміногенності місць позбавлення волі діляться на організаційні та виховні. Запобігання професійній злочинності пов'язане з реалізацією комплексу заходів, спрямованих на забезпечення належного рівня життя, повернення особи у суспільство, виховання, надання необхідної допомоги після відбуття покарання. Крім того, в рамках розглянутих заходів необхідна розробка спеціальних заходів з протидії тюремній субкультурі. За результатами проведеного дослідження внесено низку пропозицій щодо удосконалення системи запобігання професійній злочинності.

Ключові слова: професійна злочинність; виправлення; соціальна реабілітація; реінтеграція; тюремна субкультура.

В статье исследуется проблема нейтрализации криминогенности мест лишения свободы и ее влияние на профессиональную преступность. Обращается внимание на необходимость обязательного внедрения мер индивидуального предупреждения профессиональной преступности. Определено, что меры по нейтрализации криминогенности мест лишения свободы делятся на организационные и воспитательные. Предупреждение профессиональной преступности связано с реализацией комплекса мер, направленных на обеспечение должного уровня жизни, возвращение человека в общество, воспитания, оказания необходимой помощи после отбытия наказания. Кроме того, в рамках рассматриваемых мер необходима разработка специальных мер по противодействию тюремной субкультуре. По результатам проведенного исследования внесены предложения по совершенствованию системы предупреждения профессиональной преступности.

Ключевые слова: профессиональная преступность; исправление; социальная реабилитация; реинтеграция; тюремная субкультура.

Постановка проблеми. У $1920-\mathrm{x}$ роках учений-тюрмознавець С. В. Поз- нишев зазначав, що «у майбутньому, ймовірно, кожен тип злочинців знай- 
де собі місце в особливій «соціальній клініці» 3 методами «соціального лікування», що відповідають його особливостям. Але в даний час про це можна лише мріяти і будувати плани для майбутнього» [1, с. 165]. Слова відомого дореволюційного юриста не втратили своєї актуальності й сьогодні.

Як відомо, перебування в місцях позбавлення волі супроводжується впливом негативних факторів на засудженого, які носять соціальний характер і в своїй сукупності призводять до соціально-економічних, соціально-психологічних, демографічних, соціально-правових, психолого-педагогічних та кримінологічних втрат [2, с. 15].

Ці втрати пов'язані із замкнутістю міжособистісного спілкування, необхідністю виживати в постійних конфліктних ситуаціях, взаємним негативним «зараженням» між засудженими, одноманітністю соціальних функцій, необхідністю виконувати вимоги режиму, що виключає прийняття самостійних рішень, можливістю виконувати не більше $10 \%$ соціально значимих функцій, які можуть знадобитися на волі і т.д. [3, c. 67].

Виправлення професійних злочинців ускладняється не тільки їх специфікою, яка визначається неодноразовими судимостями, соціальною занедбаністю і т. Д., а й професійною деформацією працівників виправних установ - черствістю, нерозумінням цілей покарання, традиційним застосуванням виключно каральних засобів впливу. Тому діяльність виправних установ із запобігання професійній злочинності потребує кардинального перегляду. Вона повинна складатися 3 комплек- су заходів, що здатні виправити засудженого i сформувати у нього відмову від злочинної діяльності.

Аналіз останніх досліджень i публікацій. Серед науковців, які тією чи іншою мірою зверталися до даної проблематики, слід назвати Г.А. Аванесова, О. М. Бандурку, М. М. Гернета, В. В. Голіну, І. М. Даньшина, .М. Джужу, А. П. Закалюка, М. В. Корнієнка, О. М. Костенка, О. М. Литвака, О. М. Литвинова, В. І. Шакуна, О. Н. Ярмиша та ін.

Постановка завдання. Охарактеризувати негативний вплив місць позбавлення волі на стан професійної злочинності. Дослідити основні напрями нейтралізації такого впливу. 3 метою удосконалення питань щодо запобігання професійній злочинності дослідити перспективний зарубіжний досвід з цього питання.

Виклад основного матеріалу. Свого часу час для підвищення ефективності протидії професійній злочинності у виправних установах окремими авторами пропонувалися такі заходи, як: введення режиму тримання, який дасть змогу ізолювати професійних злочинців від інших засуджених; встановлення більш жорсткого порядку у виправних установах $з$ метою недопущення мобільних телефонів, наркотиків, зброї і т.п.; посилення відповідальності за злочини, вчинені у виправних установах; удосконалення кадрової роботи 3 адміністрацією установ, зі встановленням обов'язкової ротації через певний час; зміна критеріїв оцінки роботи виправних установ. Основним критерієм ефективності роботи доцільно вважати не загальну кількість усіх вчинених злочинів та правопорушень, а активність 3 їх запобігання; посилення прокурорсь- 
кого нагляду і відомчого контролю.

Окремим напрямом удосконалення системи запобігання професійній злочинності є перешкоджання поширенню тюремній ідеології, ослаблення та нейтралізація злодійських традицій, звичаїв і норм кримінального середовища

На нашу думку, тут насамперед необхідно сформувати правильне уявлення про тюремну субкультуру. Адже за всю історію вітчизняної пенітенціарної системи не було повноцінної, адекватної та комплексної програми 3 боротьби із тюремною субкультурою. За останні роки неформальні норми зазнали серйозних змін, спостерігається перехід від «злодійського закону» до нових моделей злочинної поведінки [4, с. 152153].

У нейтралізації неформальних норм поведінки велике значення мають організаційні та виховні заходи.

Індивідуум, потрапляючи до виправної установи, стоїть перед вибором: або йому керуватися неформальними нормами поведінки, або цінностями законослухняного суспільства. Від того, хто першим надасть допомогу, залежить його подальша поведінка. Коли засуджені відчувають піклування і увагу адміністрації, вони більше довіряють адміністрації виправних установ, не сприймають «злодійських» традицій.

Для запобігання правопорушенням у виправних установах і розкриття постпенітенціарних злочинів необхідно використовувати атрибутивні елементи тюремної субкультури. Йдеться про створення банку даних татуювань та прізвиськ, регулярну систематизацію тюремного жаргону.
Виховні заходи спрямовані на усвідомлення засудженим себе повноцінною особистістю, яка зазнає певних тимчасових обмежень за вчинений злочин. Без цього неможливо викорінити неформальні норми як регулятивні елементи тюремної субкультури.

Для усвідомлення засудженим себе повноцінною особистістю необхідно, по-перше, ввічливо до нього ставитися. Певний інтерес тут викликає американський досвід: «Кодекс поведінки ув'язнених у в'язниці вимагає, щоб ув'язнені зверталися до тюремних наглядачів або осіб, які відвідують установу, використовуючи звернення «сер» (до чоловіків) або «мем» (до жінок). Повага, яку в'язні повинні проявляти до тюремних наглядачів, не $\epsilon$ односторонньою. Якщо тюремний наглядач звертається до ув'язненого або викрикує його ім'я на перекличці, то він використовує звернення «містер» $[5$, c. 89].

По-друге, виховною роботою повинні займатися компетентні працівники. Така компетентність повинна виключати, з одного боку, «загравання» із засудженими, а, з другого боку, жорстокість щодо до них. Найбільш типовими $є$ деперсоналізація і дискримінація комунікативного спілкування. У першому випадку йдеться про працівників, які в силу своїх конформних рис характеру, слабких емоційно-вольових якостей, а також дефектів соціальноправових норм регуляції легко приймають «субкультуру» засуджених і нерідко переступають межу заборонених контактів. Іншим полярним варіантом комунікативного спілкування є стратегї придушення засуджених, що проявляється в над- 
мірній грубості, жорсткості та часто несправедливому поводженні з ними [6, с. 70-71].

У зв'язку з цим, з метою оздоровлення відносин і виявлення некомпетентних працівників, пропонується регулярно проводити анонімні соціологічні опитування засуджених.

Крім нейтралізації негативного впливу неформальних норм адміністрація виправних установ повинна заповнити духовний вакуум, і в цьому значну допомогу можуть надати релігійні конфесії.

Соціально-педагогічна функція релігійного впливу відіграє важливу роль і полягає у забезпеченні емоційного та інформаційного дефіциту, підготовці до законослухняного способу життя. За спостереженнями практиків, більшість засуджених завдяки релігії стають спокійнішими, врівноваженими людьми, усвідомлюють повністю тяжкість вчиненого злочину.

У перспективі розвитку кримінально-виконавчої політики є покращення умов тримання засуджених та розвиток служби пробації, основним завдання якої $є$ соціальна адаптація та ресоціалізація осіб, які відбули покарання. Ця служба повинна вирішити проблеми з працевлаштуванням, місцем проживання звільненого. Крім цього, надавати медичну, правову, психологічну, консультативну та іншу допомогу.

У цьому випадку необхідно розробити і забезпечити реалізацію державного механізму ресоціалізації осіб, які відбули покарання у виді позбавлення волі. Для цього слід запроваджувати регіональні соціальні програми, спрямовані на постпенітенціарну адаптацію звільнених після відбуття покарання.
У зазначених програмах необхідно передбачити систему стимулювання засуджених до законослухняної поведінки, до так званої системи «соціальних ліфтів», що складається із зміни умов відбування покарання, виду виправної установи, заміни невідбутої частини покарання більш м'яким видом, умовнодострокового звільнення залежно від поведінки засуджених.

I тут особливе значення має орієнтація на міжнародні стандарти, а також на позитивний досвід функціонування відповідних систем у пенітенціарних установах зарубіжних країни.

Проведений аналіз зарубіжного пенітенціарного законодавства дає змогу зробити висновок про прагнення індивідуалізувати процес стимулювання законослухняної поведінки засуджених за допомогою встановлення відкритого переліку заохочень і надання більшої компетенції у вирішенні даного питання суб'єктам, які відбувають покарання у виді позбавлення волі.

Зокрема, у другій половині XX ст. в пенітенціарній практиці ряду зарубіжних країн (США, Голландія і Данія) відбулося активне зміщення акцентів з медичної моделі, орієнтованої на примусове лікування злочинців, на реінтеграційну, яка дозволяла створити середовище, близьке до соціуму, і сприяти розвитку необхідних особистісних якостей і навичок, важливих для життя на волі.

Основними положеннями реінтеграційної моделі, що отримала надалі широкий розвиток, є такі:

- засоби боротьби зі злочинністю повинні розглядатися як засоби захисту суспільства гуманними ме- 
тодами, а не шляхом залякування індивіда;

- засоби соціального захисту повинні включати або нейтралізацію злочинця шляхом ізоляції його від суспільства (як крайній захід), або застосування до нього методів виправлення і виховання з метою ресоціалізації;

- кримінальна політика держави, заснована на положеннях доктрини нового соціального захисту, робить необхідною все більшу гуманізацію кримінального законодавства і повинна орієнтуватися більшою мірою на індивідуальне, ніж на загальне запобігання злочинності, тобто бути спрямованою на ресоціалізацію конкретного злочинця;

- робота з виправлення особистості злочинця передбачає відновлення у нього впевненості в собі, формування позитивного особистісного іміджу, почуття відповідальності з одночасним розвитком просоціальних цінностей і особистісних мотивів;

- процес гуманізації системи кримінальної юстиції має на увазі також наукове осмислення причин злочинності, вивчення особистості злочинця ще на стадії розслідування злочину, а також згодом і під час реалізації кримінального покарання, при чому переважно без ізоляції від суспільства, беручи до уваги ступінь його суспільної небезпеки [7, с. 60].

Реінтеграційна модель складається 3 послідовної реалізації трьох взаємопов'язаних між собою компонентів, що починаються 3 літери Р: реформації особистості, реабілітації соціальної, реінтеграції поетапної в суспільство.

При цьому реформація особистості здійснюється на основі даних психодіагностики за допомогою застосування індивідуальних і групових методів психокорекційного впливу.

Соціальна реабілітація досягається через ресоціалізацію засуджених у спеціальних виправних установах.

Поетапна реінтеграція в суспільство базується на психологічній підготовці і адаптації звільнених 3 місць позбавлення волі до життя на свободі, а також на соціальної реабілітації в постпенітенціарний період $[7$, c. 60].

В реінтеграційній моделі призначення покарання належить до загальної профілактики і безпеки, а головна мета виконання кожного вироку полягає в індивідуальній профілактиці, яка здійснюється за допомогою застосування такого режиму тримання, який спрямований на зміну соціальної установки засудженого і надання йому допомоги на персональному і соціально-психологічному рівнях для його соціальної реабілітації, завдяки чому він зможе в майбутньому вести законослухняний спосіб життя.

Актуальним, на наш погляд, буде приклад тюремної системи Великобританії, в рамках якої в останнє десятиліття зміцнюється статус i посилюється роль психологічної служби, до компетенції якої належать:

- розробка та впровадження класифікаційних систем ув'язнених, нових виправних програм і моделей прогнозу на основі оцінки рівня ризику при наданні умовнодострокового звільнення;

- проведення наукових досліджень, що мають вузьке прикладне значення для пенітенціарної практики; 
- участь в психологічній підготовці і атестації тюремного персоналу.

В Японії при здійсненні громадського контролю над злочинністю важливу роль відіграють заходи, спрямовані на ресоціалізацію без надмірної стигматизації звільнених 3 виправних установ, $з$ тим, щоб уникнути формування у них комплексу злочинної особи [8, с. 106-107].

Досягається це шляхом виведення зі сфери застосування кримінального законодавства осіб, які вчинили нетяжкі злочини; призначення для переважного числа осіб, визнаних винними, покарань, не пов'язаних з позбавленням волі, або позбавлення волі на нетривалі терміни; застосування диференційованого підходу в поводженні 3 ув'язненими; реалізації широкої програми контролю і виховання щодо осіб, умовно-достроково звільнених із місць позбавлення волі.

Особливий інтерес являє собою латвійський досвід, оскільки цій державі довелося «з нуля» формувати службу пробації, нормативноправову основу і організацію її діяльності, в тому числі готувати персонал до такої роботи.

Зокрема, служба пробації Латвії має наступні функції: здійснює досудові доповіді суду і прокурорам; надає допомогу особам, звільненим 3 пенітенціарних установ; розробляє i здійснює програми корекції соціальної поведінки піднаглядних осіб; координує хід виконання покарання щодо осіб, засуджених до примусових робіт; забезпечує виконання громадських робіт неповнолітніми правопорушниками; організовує процес примирення 3 допомогою посередника між потерпілими і вин- ними особами; здійснює нагляд за особами, умовно звільненими від кримінальної відповідальності, умовно засудженими та умовнодостроково звільненими, а також надає їм необхідну допомогу.

В Україні 5 лютого 2015 р. було прийнято Закон України «Про пробацію», який введено у дію 27 серпня 2015 року.

Відповідно до вказаного закону пробація - це система наглядових та соціально-виховних заходів, що застосовуються за рішенням суду та відповідно до закону до засуджених, виконання певних видів кримінальних покарань, не пов'язаних з позбавленням волі, та забезпечення суду інформацією, що характеризує обвинуваченого.

Суть пробації полягає у встановленні нагляду за засудженим з покладенням на нього певних зобов'язань і обмежень, без ізоляції його від суспільства (відвідувати центри пробації, періодично зустрічатися з наглядовим офіцером, брати участь у певних різновидах діяльності, дотримуватися законослухняної поведінки тощо).

Метою пробації $є$ забезпечення безпеки суспільства шляхом виправлення засуджених, запобігання вчиненню ними повторних кримінальних правопорушень та забезпечення суду інформацією, що характеризує обвинувачених, 3 метою прийняття судом рішення про міру їхньої відповідальності.

Під час вирішення питання про застосування до особи пробації суд бере до уваги характер вчиненого кримінального правопорушення та соціально-психологічну характеристику особи обвинуваченої або засудженої, яку готує персонал органу 
пробації або адміністрація установи виконання покарань.

Попри усі недоліки Закону України «Про пробацію», які досі піддаються критиці та потребують подальшого удосконалення, за оцінками міжнародних експертів цей Закон відповідає європейським стандартам пробації.

Національна модель пробації передбачає роботу на етапі судового розгляду (досудова пробація - забезпечення суду формалізованою інформацією, що характеризує обвинуваченого, 3 метою прийняття судом рішення про міру його відповідальності).

Після застосування покарання, альтернативного позбавленню волі, розпочинається етап наглядової пробації, яка передбачає не лише контроль за засудженим, а й індивідуально сплановану роботу над вирішенням його проблем (факторів ризику), які можуть призвести до вчинення повторного злочину, забезпечення надання йому необхідних соціальних, психологічних, юридичних, медичних та освітніх послуг; застосування спеціальних пробаційних програм. В основі усіх пробаційних заходів перебуває оцінка факторів ризику та використання спеціальних методик пробаційної роботи, які ураховують стать та вік суб'єкта пробації, передбачають постійний моніторинг результатів і коригування для досягнення максимального ефекту. До роботи із суб'єктами пробації, яка базується на ресурсах громади, можуть залучатися волонтери пробації.

Пробація також передбачає сприяння адміністрації установ закритого типу у вирішенні для засуджених, які звільняються, питань оформлення документів, проживання, роботи, поміщення до закладів соціального захисту або лікарень (тих хто потребує лікування).

Положення, передбачені Законом України «Про пробацію», були узгоджені з іншими законами шляхом прийняття Закону України від 7 вересня 2016 р. № 1492-VIII «Про внесення змін до деяких законодавчих актів України щодо забезпечення виконання кримінальних покарань та реалізації прав засуджених».

Зазначеним Законом внесено зміни до Кримінального кодексу, Кримінально-виконавчого кодексу та Кримінального процесуального кодексу, зокрема до переліку органів виконання покарань внесено уповноважений орган з питань пробації, урегульовано 3 іншими законами порядок складання досудової доповіді, здійснення пробаційного нагляду, реалізацію пробаційних програм та здійснення заходів пенітенціарної пробації.

Водночас певну запобіжну роль у зменшенні рівня професійної злочинності відіграють заходи із виявлення та постановки на облік осіб, які звільнилися з установ виконання покарань, які вчинили тяжкі та особливо тяжкі злочини, а також засуджених за умисні злочини до покарань, не пов'язаних із позбавленням волі. Місцеві правоохоронні органи мають налагодити ефективний контроль за своєчасним прибуттям, документуванням і реєстрацією осіб, які звільнилися після відбуття покарання. Таким особам потрібно сприяти у влаштуванні на роботу та у налагоджені й облаштуванні їх побуту.

Важливий профілактичний ефект у запобіганні професійній зло- 
чинності міститься у профілактичному контролі за особами, які після звільнення потребують адміністративного нагляду. Відповідно до положень Закону України «Про адміністративний нагляд за особами, звільненими з місць позбавлення волі» такий нагляд установлюється щодо повнолітніх осіб: засуджених до позбавлення волі за тяжкі, особливо тяжкі злочини або засуджених два i більше разів до позбавлення волі за умисні злочини, якщо під час відбування покарання їх поведінка свідчила, що вони вперто не бажають стати на шлях виправлення і залишаються небезпечними для суспільства; щодо засуджених до позбавлення волі за тяжкі, особливо тяжкі злочини або засуджених два і більше разів до позбавлення волі за умисні злочини, якщо вони після відбування покарання або умовно-дострокового звільнення від відбування покарання, незважаючи на попередження органів Національної поліції, систематично порушують громадський порядок i права інших громадян, вчиняють інші правопорушення; щодо засуджених до позбавлення волі за один із злочинів, пов'язаних 3 незаконним обігом наркотичних засобів, психотропних речовин і прекурсорів.

Як окремий запобіжний захід можна виділити необхідність створення і використання єдиної спеціальної бази даних про професійних злочинців. Така база має бути автоматизованою, містити фотографії, анкетні дані, розгорнуту інформацію про вчинені правопорушення, а також про родинні, дружні й кримінальні зв'язки, поведінку під час відбування покарання, способи вчинення ними злочинів, а також будь-яку ін- шу інформацію, що являє собою інтерес для правоохоронних органів [9].

Для покращення ефективності запобігання професійній злочинності важливо мати у своєму розпорядженні статистичну інформацію про поточний стан і динаміку злочинності (в тому числі й професійної злочинності); місця, територію та об'єкти, де професійними злочинцями вчиняється найбільша кількість злочинів; про соціальні, економічні та інші фактори, що впливають на стан того чи іншого виду злочинносTi.

Реалізація цих завдань можлива за допомогою застосування апробованих методів кримінологічних досліджень. До таких, зокрема, належать:

- статистичний аналіз показників поточної професійної злочинності порівняно з аналогічним періодом минулого року (ще більш достовірні результати динаміки і подальших тенденцій професійної злочинності можуть бути отримані, якщо порівнювати іï рівень за три, п'ять, 10 років);

- узагальнення інформації, що міститься в матеріалах кримінальних справ, про обставини, які сприяли вчиненню професійними злочинцями злочинів;

- внесення в систему обліку та звітності правоохоронних органів самостійного розділу про професійну злочинність;

- побудова і поповнення банків даних криміналітету, електронне стеження за професійними злочинцями в усіх органах кримінальної юстиції для аналізу криміногенних ситуацій, що складаються в їх середовищі; 
- моніторинг громадської думки.

Висновки. Таким чином, нейтралізація криміногенності місць позбавлення волі пов'язана з реалізацією комплексу заходів, спрямованих на реалізацію прогресивної системи відбування покарання, зниження рівня ізоляції засуджених у місцях позбавлення волі; диференціації за- суджених; нейтралізацію тюремної субкультури; застосування режимних заходів у місцях позбавлення волі; проведення виховної роботи 3 засудженими із залученням представників різних релігійних конфесій; удосконалення постпенітенціарного контролю і нагляду; соціальну допомогу засудженим після звільнення.

\section{Список використаних джерел}

1. Познышев С. В. Основы пенитенциарной науки. Москва, 1923. 342 с.

2. Рудник В.И. Отрицательные последствия применения уголовного наказания в виде лишения свободы и основные меры их нейтрализации: автореф. дис. ... канд. юрид. наук. Киев, 1990. 25 с.

3. Зелинский А. Ф. Рецидив преступлений: структура, связи, прогнозирование. Харьков : Изд-во Харьковского юридического института, 1980.132 с.

4. Хохряков Г. Ф. Парадоксы тюрьмы. Москва : Юрид. лит., 1991. 224 с.

5. Система перевоспитания заключенных в тюрьме города Монтгомери в США. Передовой опыт уголовно-исполнительной системы. Москва : МВД России, 1997. Вып. 12. C. 86-92.

6. Лебедев В. В. Формирование профессиональной компетентности сотрудников ИТУ: состояние, проблемы. Личность преступника и исполнение уголовных наказаний: сб. науч. трудов. Москва : ВНИИ МВД СССР, 1991. С. 70-71.

7. Поздняков В. М. Психология в пенитенциарной практике зарубежных стран в XX столетии (историко-сравнительный анализ). Москва : Изд-во Акад. управления МВД России, 2000. 149 с.

8. Морозов Н. А. Преступность и борьба с ней в современной Японии: дис. ... канд. юрид. наук. Владивосток, 2000. 193 с.

9. Кошко А.Ф. Очерки уголовного мира царской России. Москва : ДиректМедиа, 2014. Т. 1.83 с.

\section{References}

Poznyshev, S. V. (1923). Osnovy penitenciarnoj nauki. Moskva [in Russian].

Rudnik, V. I. (1990). Otricatelnye posledstviya primeneniya ugolovnogo nakazaniya $v$ vide lisheniya svobody i osnovnye mery ih nejtralizacii (Avtoref. dis. ... kand. yurid. nauk). Kiev [in Russian].

Zelinskij, A. F. (1980). Recidiv prestuplenij: struktura, svyazi, prognozirovanie. Harkov: Izd-vo Harkovskogo yuridicheskogo instituta [in Russian].

Hohryakov, G. F. (1991). Paradoksy tyurmy. Moskva: Yurid. lit. [in Russian].

Sistema perevospitaniya zaklyuchennyh $\mathrm{v}$ tyurme goroda Montgomeri $\mathrm{v}$ SShA. (1997). Peredovoj opyt ugolovno-ispolnitelnoj sistemy. Moskva: MVD Rossii, 12, 86-92 [in Russian].

Lebedev, V. V. (1991). Formirovanie professionalnoj kompetentnosti sotrudnikov ITU: sostoyanie, problemy. Lichnost prestupnika i ispolnenie ugolovnyh nakazanij: sb. nauch. trudov. Moskva: VNII MVD SSSR, 70-71 [in Russian]. 
Pozdnyakov, V. M. (2000). Psihologiya v penitenciarnoj praktike zarubezhnyh stran $v$ XX stoletii (istoriko-sravnitelnyj analiz). Moskva: Izd-vo Akad. upravleniya MVD Rossii [in Russian].

Morozov, N. A. (2000). Prestupnost i borba s nej v sovremennoj Yaponii (Dis. ... kand. yurid. nauk). Vladivostok [in Russian].

Koshko, A. F. (2014). Ocherki ugolovnogo mira carskoj Rossii. Moskva [in Russian].

N. Makarenko, PhD, Assistant Professor, Doctoral Candidate of Department of Criminology and the Penal Law of National Academy of Internal Affairs

ORCID: 000-0003-3089-3535

\section{Neutralization of criminogenity of places of detention as a direction of prevention of professional crime}

The article explores the problem of neutralizing the criminogenicity of places of deprivation of liberty and its impact on professional crime. Attention is drawn to the need for mandatory implementation of individual measures to prevent professional crime.

It was determined that measures to neutralize the criminality of places of deprivation of liberty are divided into organizational and educational.

Prevention of professional crime is associated with the implementation of a set of measures aimed at ensuring an adequate standard of living, returning a person to society, education, and providing the necessary assistance after serving the sentence. In addition, as part of the measures under consideration, it is necessary to develop special measures to counter the prison subculture.

According to the results of the research, a number of proposals were made to improve the system of prevention of professional crime.

It is about further improving the conditions of detention, the development of the probation service, the use of religious influence, the introduction of regional social programs aimed at post-penitentiary adaptation of those released after serving their sentences.

The issue of introduction of reintegration model of punishment serving, which should consist of three components: individual reformation, social rehabilitation, reintegration step by step, is considered separately.

As a separate precautionary measure stands out the need to create and use a single special database on professional offenders.

Keywords: professional crime; correction; social rehabilitation; reintegration; prison subculture. 